\title{
MARCIN SKORB
}

\author{
Akademia Ekonomiczna w Poznaniu
}

\section{STAN CYWILNOPRAWNEJ OCHRONY KONSUMENTA USEUG UBEZPIECZENIOWYCH W POLSCE}

Artykuł niniejszy dotyczy materii cywilnoprawnej ochrony konsumenta będącego biorcą usługi ubezpieczeniowej, znajdującej się w aktualnych regulacjach prawnych. Asumpt do zajęcia się tą tematyką dały istotne zmiany legislacyjne w tym zakresie, które dokonały się w ostatnim czasie. Wśród zmian tych należy wskazać przede wszystkim nowelizacje kodeksu cywilnego, które weszły w życie w dniu 25 września 2003 roku $^{1}$ oraz w dniu 1 stycznia 2004 roku $^{2}$, a także wejście w życie nowej ustawy o dzialalności ubezpieczeniowej (obok trzech innych nowych ustaw ubezpieczeniowych) również z dniem 1 stycznia 2004 roku $^{3}$, które to zmiany wywarły istotny wpływ na omawianą problematykę. Należy zaznaczyć, że ochrona konsumenta w ogóle, a w tym konsumenta usług finansowych jest cały czas rozszerzana $\mathrm{z}$ uwagi na rosnace potrzeby w tym zakresie. Sytuacja taka jest bardzo wyraźnie widoczna w prawie polskim, które dostosowuje się także i w tym zakresie do prawa Unii Europej-

${ }^{1}$ Wprowadzona ustawą z dnia 14 lutego 2003 r. o zmianie ustawy - Kodeks cywilny oraz niektórych innych ustaw (Dz.U. Nr 49, poz. 408)

${ }^{2}$ Wprowadzona ustawą z dnia 22 maja 2003 r. o działalności ubezpieczeniowej (Dz.U. Nr 124, poz. 1151).

${ }^{3}$ Ustawa z dnia 22 maja 2003 r. o działalności ubezpieczeniowej (Dz.U. Nr 124, poz. 1151). 
skiej, gdzie ochrona ta jest dużo bardziej ugruntowana - choć również, jak się wydaje, nie przybrała jeszcze ostatecznego ksztaltu. Tak więc aktualny stan omawianej ochrony prawnej znajduje się cały czas w fazie intensywnego rozwoju i z pewnością będzie się jeszcze zmienial. Dotyczy to oczywiście także ochrony konsumenta usługi ubezpieczeniowej. Artykuł ten wskazuje na aktualne regulacje, ale należy mieć na względzie, iż w niedalekiej przyszłości moga one ulegać dalszym zmianom. Z uwagi na obszerność tematu skoncentrowano się jedynie na wybranych zagadnieniach cywilnoprawnych mając świadomość, iż opracowanie niniejsze nie wyczerpuje całości problematyki.

\section{DEFINICJA KONSUMENTA}

Podstawowym zagadnieniem w ramach przedstawianego tematu, którym należy zając się na wstępie, jest pojęcie konsumenta. Pojęcie to jest obecnie zdefiniowane w kodeksie cywilnym, a we wrześniu 2003 r. w wyniku nowelizacji kodeksu cywilnego zostało ono istotnie zmienione. Należy jednak zauważyć, iż definicja ta pojawila się po raz pierwszy w kodeksie cywilnym dopiero w 2000 r. (w wyniku zmian k.c. wprowadzonych z dniem 1.07.2000 r. ${ }^{4}$ ). Wcześniej definicje tego pojęcia znajdowały się jedynie w aktach prawnych szczególnych, gdzie zamieszczano je na potrzeby danego aktu prawnego i problematyki, którą on regulowal. W kodeksie cywilnym pojęcie konsumenta istniało (było elementem języka prawnego), lecz do 2000 r. nie bylo zdefiniowane. Przykładem może być poprzednia treść art. 384 k.c., który zawieral delegację ustawową dla Rady Ministrów do określenia w drodze rozporządzenia szczegółowych warunków zawierania i wykonywania umów z udziałem konsumentów w wypadkach, gdy wymagała tego ochrona interesów

\footnotetext{
${ }^{4}$ Ustawą z dnia 2 marca 2000 r. o ochronie niektórych praw konsumentów oraz o odpowiedzialności za szkodę wyrządzoną przez produkt niebezpieczny (Dz.U. Nr 22, poz. 271).
} 
konsumentów. W dalszej części opracowania skoncentruję się jednak na samej definicji legalnej pojęcia „konsument”. Pierwsza definicja zamieszczona w kodeksie cywilnym w $2000 \mathrm{r}$. za konsumenta uważała „osobę, która zawiera umowę z przedsiębiorcą w celu bezpośrednio nie związanym z działalnością gospodarczą"5. Natomiast nowelizacja k.c. z września 2003 r. wprowadziła nową, zmienioną definicję, zgodnie z którą „za konsumenta uważa się osobę fizyczną dokonującą czynności prawnej niezwiązanej bezpośrednio z jej działalnością gospodarczą lub zawodową". Ustawodawca wprowadzil więc następujące zmiany w stosunku do pierwotnej definicji:

- Po pierwsze: obecnie konsumentem jest nie każda osoba, ale tylko osoba fizyczna. Jest to znaczące zawężenie zakresu podmiotowego w stosunku do definicji pierwotnej. Zresztą wprowadzone słusznie, gdyż trudno było zgodzić z się z argumentacją, iż szczególnej ochrony prawnej $w$ stosunkach $z$ przedsiębiorcami należy udzielać także osobom prawnym, które często posiadały ten sam stopień profesjonalizmu co przedsiębiorca $\mathrm{z}$ którym zawierały umowę, a niejednokrotnie wyższy.

- Po drugie: obecna definicja dotyczy czynności prawnych dokonywanych przez konsumenta, a nie tylko zawierania przez niego umów $\mathrm{z}$ przedsiębiorcą, jak to miało miejsce w poprzedniej definicji. Mamy tu więc do czynienia z rozszerzeniem z kolei zakresu przedmiotowego tej definicji.

- Po trzecie: obecna definicja dotyczy czynności prawnych niezwiązanych bezpośrednio zarówno z działalnością gospodarczą konsumenta, jak i jego działalnością zawodową. Rozszerzono więc zakres definicji o działalność zawodową która nie jest, zgodnie z obowiązującym prawem, działalnością gospodarczą. Rozwiązanie takie wydaje się słuszne, ponieważ nie ma przesłanek ku temu, aby reżimem ochrony konsumenta obejmować czynności związane $\mathrm{Z}$ wykonywaną profesją, gdyż w tym zakresie dana osoba posiada

${ }^{5}$ Art. $384 \$ 3$ k.c. w brzmieniu z dnia 1 lipca 2000 r.

${ }^{6}$ Art. $22^{1}$ k.c. 
odpowiednią wiedzę i można ja uznać za profesjonalistę. Dotyczyć to będzie w szczególności tzw. wolnych zawodów, których wykonywanie w niektórych przypadkach nie jest uznawane za działalność gospodarczą w rozumieniu przepisów ustawy - Prawo działalności gospodarczej ${ }^{7}$.

W wyniku tych zmian polska definicja konsumenta została dostosowana do definicji znajdujących się w aktach prawnych Unii Europejskiej, gdzie konsument rozumiany jest w większości wypadków jako właśnie osoba fizyczna, która działa w celach niezwiązanych z działalnością gospodarczą, przedsiębiorstwem lub zawodem. Istnieje jednak pewna różnica. Mianowicie w definicji polskiej zawarte jest wyrażenie „bezpośrednio”, którego nie znajdziemy w definicjach UE. Tak więc w prawie polskim konsumentem będzie osoba dokonująca czynności prawnej niezwiązanej bezpośrednio z jej działalnością gospodarczą lub zawodową. Przyjąć więc należy, że jeżeli będziemy mieli do czynienia z czynnością pośrednio tylko związaną z działalnością gospodarczą lub zawodową, to będziemy mogli mówić o konsumencie. Jest to wyrażenie bardzo nieprecyzyjne, ponieważ w konkretnych przypadkach trudno będzie określić jakie czynności są związane tylko pośrednio, a jakie bezpośrednio z daną dzialalnością gospodarczą lub zawodową. Sprawia to, iż definicja konsumenta jest nie do końca czytelna i będzie musiała być doprecyzowana przez doktrynę i orzecznictwo. De lege ferenda należałoby postulować wykreślenie $z$ definicji bezpośredniego powiązania z działalnością gospodarczą lub zawodową, aby uniknąć nieuniknionych w tym zakresie rozbieżności interpretacyjnych. Nie widzę żadnego uzasadnienia dla takiego zawężania tej definicji. Zresztą postulat taki nie jest nowy. Już na etapie prac legislacyjnych dotyczących nowelizacji kodeksu cywilnego, która wprowadzila definicję konsumenta, postulowano wykreślenie wyrażenia „bez-

${ }^{7}$ Por. art. 87 ustawy z dnia 19 listopada 1999 r. - Prawo działalności gospodarczej (Dz.U. z 1999 r. Nr 101, poz. 1178), zgodnie z którym świadczący pomoc prawną oraz pomoc w zakresie własności przemysłowej nie jest przedsiębiorcą w rozumieniu przepisów tej ustawy. 
pośrednio" (taką poprawkę zaproponowal Senat), jednak postulat ten nie znalazł odpowiedniego poparcia w głosowaniu sejmowym.

Na gruncie ubezpieczeń za konsumenta należy więc rozumieć ubezpieczającą osobę fizyczną dokonującą czynności prawnej dotyczącej zawarcia lub realizacji umowy ubezpieczenia niezwiązanej bezpośrednio z jej działalnością gospodarczą lub zawodową. Jednak definicja ta na gruncie umowy ubezpieczenia nabrała innego znaczenia w związku ze zmianą kodeksu cywilnego wprowadzoną od 1 stycznia 2004 r. Zmiana ta opisana zostanie w dalszej części artykułu.

\section{PROBLEMATYKA PRZEPISÓW OGÓLNYCH O ZOBOWIĄZANIACH UMOWNYCH KODEKSU CYWILNEGO W KONTEKŚCIE STOSUNKU UBEZPIECZENIOWEGO}

Przepisy tytułu III księgi trzeciej k.c. zawierają istotne regulacje dotyczące ochrony konsumenta w stosunku umownym. Przede wszystkim dotyczą one sytuacji zawierania umów przy pomocy tzw. wzorca umownego, którym są w szczególności ogólne warunki umów, wzory umów i regulaminy. W przypadku umowy ubezpieczenia, która jest przedmiotem zainteresowania niniejszego opracowania, będą to ogólne warunki ubezpieczeń tworzone przez zakłady ubezpieczeń. We wskazanym tytule k.c. znajdują się unormowania, które w zakresie stosunku ubezpieczeniowego dotyczą m.in. takich kwestii jak: sposób zaznajomienia się konsumenta $\mathrm{z}$ treścią ogólnych warunków ubezpieczeń, reguly interpretacyjne postanowień ogólnych warunków ubezpieczeń oraz skutki zastosowania tzw. niedozwolonych postanowień umownych (klauzul abuzywnych) przez zakład ubezpieczeń w ogólnych warunkach ubezpieczeń. Powyższe zagadnienia zostaną przedstawione poniżej, w celu zasygnalizowania tej problematyki na gruncie stosunku ubezpieczeniowego.

Przede wszystkim należy zwrócić uwagę na kontrowersyjną zmianę art. 384 k.c. Otóż z dniem 1.01.2004 r. ustawa z dnia 22 maja 
2003 r. o działalności ubezpieczeniowej dodała do tegoż art. \$5 zgodnie z którym ,w przypadku umowy ubezpieczenia przepisy niniejszego tytułu stosuje się do stron umowy, także gdy ubezpieczający nie jest konsumentem". W konsekwencji od 1.01.2004 r. wszelkie regulacje ochronne wynikające $\mathrm{z}$ przepisów tytułu III księgi III k.c. dotyczące konsumenta, będą dotyczyły również każdego, kto wystąpi w umowie ubezpieczenia jako ubezpieczający, niezależnie od tego czy jest konsumentem czy nie. Tak więc obecnie na gruncie cywilnoprawnej ochrony ubezpieczającego konsumenta mamy do czynienia $\mathrm{z}$ dwoma rodzajami sytuacji:

1. Sytuacja, w której przepisy prawa cywilnego chroniące interes konsumenta stosujemy wyłącznie do konsumenta usługi ubezpieczeniowej, a więc osoby fizycznej zawierającej umowę ubezpieczenia nie związaną bezpośrednio z jej dzialalnością gospodarczą lub zawodową. Przepisów tych nie będziemy stosować do innych ubezpieczających np. osób prawnych czy też osób fizycznych zawierających umowy ubezpieczenia związane z prowadzeniem działalności gospodarczej lub zawodowej. Do grupy tych przepisów należą wszelkie regulacje prawa cywilnego zawierajace normy chroniące interes konsumenta z wyjątkiem przepisów tytułu III księgi III k.c. Podkreślić należy, iż do tej grupy należeć będą nie tylko regulacje kodeksu cywilnego, ale $\mathrm{i}$ inne unormowania prawa cywilnego np. przepisy chroniące interes konsumenta w przypadku zawierania umów ubezpieczenia na odległość.

2. Sytuacja, w której przepisy prawa cywilnego chroniące interes konsumenta stosujemy nie tylko wobec konsumenta usługi ubezpieczeniowej, ale także wobec każdego ubezpieczającego. Do tej grupy unormowań należą jedynie przepisy tytułu III księgi III k.c. Tej właśnie sytuacji poświęcona zostanie dalsza część opracowania.

Należy się zastanowić, czy wprowadzenie tak szerokiej ochrony ubezpieczającego było słuszne. Moim zdaniem jest to ochrona zbyt daleko idąca i nie uzasadniona (takie też stanowisko przyjmuje się powszechnie w literaturze przedmiotu). Rozpatrując tą kwestię trzeba sobie odpowiedzieć na podstawowe pytanie: czy przedsiębiorca zawierający umowę ubezpieczenia związaną z prowadzoną 
przez niego działalnością gospodarczą wymaga takiej samej ochrony jak konsument zawierający umowę ubezpieczenia? Trudno znaleźć argumentacje dla pozytywnej odpowiedzi na to pytanie. Przedsiębiorca jako profesjonalista, działający na rynku i mający wiedzę potrzebną dla zawierania różnego rodzaju umów w obrocie gospodarczym nie potrzebuje specjalnej ochrony jaką system prawny przewiduje dla niedoświadczonego, nie posiadającego odpowiedniej wiedzy i środków konsumenta. Nie ma powodów aby w stosunku pomiędzy dwoma przedsiębiorcami, z których jeden jest ubezpieczającym, a drugi zakładem ubezpieczeń, specjalna ochrona prawna obejmować miała tylko jednego z nich, a mianowicie ubezpieczającego. Choć wypada zauważyć, że zakład ubezpieczeń zawsze jest bardzo silnym podmiotem na rynku, posiadającym odpowiednie środki i odpowiednio wykwalifikowany personel, aby precyzyjnie zadbać o swoje interesy (wynika to chociażby z faktu nałożenia na zakłady ubezpieczeń rygorystycznych warunków co do środków finansowych, które powinny na podstawie szczególowych regulacji prawnych posiadać oraz narzucenia formy prawnej $\mathrm{w}$ jakiej mogą prowadzić działalność - spółki akcyjnej lub towarzystwa ubezpieczeń wzajemnych). Natomiast tym drugim przedsiębiorcą, który jest ubezpieczającym może być mały przedsiębiorca, który nie posiada takich możliwości i wiedzy jak zakład ubezpieczeń. To zapewne bylo przyczyną objęcia przez ustawodawcę ochroną konsumencką także przedsiębiorców, którzy zawierają umowy ubezpieczenia z podmiotem, który charakteryzuje się ścisłym profesjonalizmem w tej dziedzinie, czyli zakładem ubezpieczeń. Zwłaszcza, że stopień skomplikowania umów ubezpieczenia, a przede wszystkim tworzonych przez zakłady ubezpieczeń ogólnych warunków ubezpieczeń jest coraz większy. Także liczba obszarów działania, w których zawiera się umowy ubezpieczenia wciąż rośnie.

Biorąc pod uwagę powyższe i nie znajdując uzasadnienia dla tak szerokiej ochrony ubezpieczających jak ta wprowadzona przez ustawodawcę w art. $384 \$ 5$ uważam, iż należałoby rozważyć de lege ferenda zawężenie omawianej regulacji tylko do osoby fizycznej będącej ubezpieczającym. Przy takiej koncepcji przepis ten mógłby 
brzmieć w sposób następujący: $W$ przypadku umowy ubezpieczenia przepisy niniejszego tytutu stosuje się do stron umowy, także gdy ubezpieczajacy będacy osoba fizycznq, nie jest konsumentem. Regulacja taka obejmowałaby więc ubezpieczające osoby fizyczne prowadzące działalność gospodarczą, a nie dotyczyłaby osób prawnych, których organizacja i posiadany potencjał nie uprawniają do objęcia ich wyjątkową ochroną, jaką przyznaje się konsumentowi. Takie rozwiązanie, gdzie regulacja ochronna dotyczy jedynie ubezpieczającej osoby fizycznej zostało już zastosowane przez ustawodawcę. Mianowicie w art. $812 \$ 3$ k.c. w jego nowym brzmieniu, ustawodawca nakłada na zakład ubezpieczeń obowiązek informacyjny, który dotyczy jedynie osoby fizycznej, będącej ubezpieczającym. Przepis ten stanowi, iż ,zakład ubezpieczeń udziela ubezpieczającemu, będącemu osobą fizyczną, informacji o sposobie i trybie rozpatrywania skarg i zażaleń zgłaszanych przez ubezpieczającego lub uprawnionego z umowy ubezpieczenia, a także informacji o organie właściwym do ich rozpatrzenia." Tak więc regulacja ta, mająca na celu wskazanie ubezpieczającemu sposobu rozpatrywania jego skarg, nie dotyczy ubezpieczającego będącego osobą prawną. Ustawodawca uznat, iż informacja taka potrzebna jest jedynie osobie fizycznej, natomiast osoba prawna posiadająca zazwyczaj większy stopień profesjonalizmu takiej informacji nie potrzebuje. Może należałoby pójść właśnie tym tropem także przy zwiększaniu zakresu ochrony konsumenckiej przy umowie ubezpieczenia.

Zaproponowane rozwiązanie spowodowałoby, iż osoba fizyczna, która często prowadzi działalność gospodarczą w małych rozmiarach w postaci zakładu rzemieślniczego czy usługowego lub też małą firmę rodzinną objęta zostałaby ochroną konsumencką w jej relacji ze ścisłym profesjonalistą, jakim jest zakład ubezpieczeń. Nie różnicowałoby się wówczas sytuacji osoby fizycznej w zależności od tego czy zawiera umowę ubezpieczenia dla celów prywatnych czy też dla celów związanych z prowadzoną działalnością gospodarczą. Przecież w obu tych przypadkach występuje ta sama osoba i jej poziom wiedzy oraz przygotowania do ochrony swoich interesów w stosunku z zakładem ubezpieczeń jest taki sam. Przykładowo 
można wyobrazić sobie sytuację, iż osoba fizyczna prowadzi sklep czy zakład produkcyjny i ubezpiecza budynek w którym się on znajduje - występuje wówczas jako niekonsument, a zaraz potem ubezpiecza swoje mieszkanie prywatne i wówczas występuje już w roli konsumenta. Podobnie rzecz się ma np. z samochodem używanym do prowadzenia działalności gospodarczej i drugim używanym tylko dla celów prywatnych. Pozycja takiej osoby wobec zakładu ubezpieczeń w przedstawionych sytuacjach nie zmienia się. Moim zdaniem takie ujęcie zwiększonej ochrony ubezpieczającego dałoby się obronić dużo łatwiej niż zastosowanie ochrony wobec wszystkich ubezpieczających, a więc także do dobrze najczęściej zorganizowanych osób prawnych zawierających umowy ubezpieczenia, jak to ma miejsce w obecnej regulacji.

Chciałbym też zwrócić uwagę na brak konsekwencji ustawodawcy przy wprowadzaniu zmian do art. 384 k.c. Nie zrozumiałe jest dlaczego podobną ochroną, jak ta przyznana ubezpieczającemu, nie obją on osób zawierających umowy z bankami. W przypadku umów bankowych sytuacja jest bardzo podobna do tej występującej przy umowach ubezpieczeniowych. Również jedną ze stron umowy jest ścisły profesjonalista jakim jest bank, umowa często jest skomplikowana i dotyczy zagadnień, co do których wiedza klienta banku jest znikoma oraz, co bardzo ważne, zawierana jest najczęściej również przy użyciu wzorca umownego jakim są regulaminy bankowe. Skoro ustawodawca zdecydował się na zwiększoną ochronę ubezpieczającego, to taką samą ochroną powinien objąc zawierającego umowę bankową z bankiem. Myślę, że ta kwestia będzie przedmiotem dyskusji i znajdzie swój final w nowych regulacjach prawnych. Oczywiście uwagi, co do zakresu ochrony przyznanej „słabszej” stronie umowy ubezpieczeniowej, odnoszą się także do ewentualnego objęcia taką ochroną "słabszej" strony umowy bankowej. Kwestią otwartą pozostaje zakres podmiotowy takiej ochrony.

Omawiając zmianę k.c. polegającą na dodaniu do art. 384 paragrafu 5 należy także zwrócić uwagę, iż zmiana taka ma z kolei pozytywne przełożenie na sytuację prawną osób ubezpieczanych przez przedsiębiorców. W momencie, gdy specjalna ochrona dotyczyła 
jedynie konsumenta zawierającego umowę ubezpieczenia, to przywileje wynikające z tej ochrony nie dotyczyły konsumentów, którzy byli ubezpieczani, ale nie występowali jako strona umowy ubezpieczenia. Ubezpieczającym w takim przypadku był przedsiębiorca np. zakład pracy ubezpieczający swoich pracowników czy też biuro podróży ubezpieczające swoich klientów, w związku z tym na podstawie poprzedniej regulacji prawnej nie można było mówić o umowie konsumenckiej. Objęcie obecnie reżimem ochrony konsumenta także takich ubezpieczających jest korzystne dla ubezpieczanych przez nich konsumentów, którzy nie będąc stroną umowy ubezpieczenia korzystają z dobrodziejstw specjalnej ochrony, jaka przysługuje ubezpieczającym ich przedsiębiorcom. Kwestia ta również wymaga zastanowienia przy ewentualnych zmianach omawianych regulacji, tak aby utrzymać korzyści płynące ze zmian dla ubezpieczanych przez przedsiębiorców konsumentów zwłaszcza, że np. ubezpieczanie swoich pracowników przez pracodawców staje się coraz powszechniejsze.

Problematyka związania stron umowy ubezpieczenia ogólnymi warunkami ubezpieczenia byla już wielokrotnie rozpatrywana w literaturze przedmiotu, stąd w tym miejscu skoncentruję się jedynie na kilku uwagach dotyczących tej problematyki w kontekście przyznania statusu konsumenta każdemu ubezpieczającemu na podstawie art. $384 \$ 5$. Zgodnie z art. $384 \$ 1$ k.c. ustalony przez jedną ze stron (w tym wypadku zakład ubezpieczeń) wzorzec umowy wiąże druga stronę, jeżeli został jej doręczony przy zawarciu umowy. Jednak, gdy posługiwanie się danym wzorcem umowy jest zwyczajowo przyjęte w stosunkach danego rodzaju, wiąże on także wówczas, gdy druga strona mogła z łatwością dowiedzieć się o jego treści. Unormowanie to nie dotyczy jednak umów zawieranych z udziałem konsumentów. Tak więc przy umowach konsumenckich wzorzec umowy wiąże jedynie wówczas, gdy został doręczony przy zawarciu umowy, bez względu na to czy konsument mógl się z łatwością dowiedzieć o jego treści czy też nie. Wyjątkiem są tutaj umowy powszechnie zawierane w drobnych, bieżących sprawach życia codziennego. W związku $z$ art. $384 \$ 5$ stanowiącym, iż w przypadku 
umowy ubezpieczenia przepisy te stosuje się do stron umowy, także gdy ubezpieczający nie jest konsumentem, należy przyjąć, iż ogólne warunki ubezpieczeń tworzone przez zakłady ubezpieczeń wiążą ubezpieczającego tylko wówczas, gdy zostały mu doręczone. Nie ma przy tym znaczenia, czy ubezpieczający jest konsumentem w rozumieniu kodeksu cywilnego, czy też nie. Zgodnie więc z obowiązującym obecnie stanem prawnym nawet gdy ubezpieczającym jest przedsiębiorca, będzie on związany postanowieniami ogólnych warunków ubezpieczenia tylko wówczas, gdy zostały mu one doręczone. Wydaje się, iż w przypadku umowy ubezpieczenia nie będzie miał zastosowania wyjątek dotyczący umów powszechnie zawieranych w drobnych, bieżących sprawach życia codziennego. Trudno sobie bowiem wyobrazić jakąkolwiek umowę ubezpieczenia dotyczącą drobnych, bieżących spraw życia codziennego. W sprawach takich nie zawiera się umów ubezpieczenia, które dotyczą zdarzeń mogących nastąpić w przyszłości, z pewnością nie będących drobnymi, bieżącymi sprawami życia codziennego.

Skoro ogólne warunki ubezpieczeń muszą być doręczone, aby wiązały ubezpieczającego, to pojawia się pytanie w którym momencie to doręczenie powinno nastąpić. Zgodnie $z$ art. $384 \$ 1$ doręczenie to powinno nastąpić przy zawarciu umowy. Abstrahując od tego, że w praktyce trudno określić co dokładnie oznacza zwrot „przy zawarciu umowy" należy zwrócić uwagę, iż ustawodawca wprowadzając zmiany cytowaną już ustawą z dnia 22 maja 2003 r. o działalności ubezpieczeniowej zmienił w stosunku do umowy ubezpieczenia to sformułowanie. Zgodnie $\mathrm{z}$ nowym brzmieniem art. 812 § 1 k.c. zakład ubezpieczeń ma obowiązek doręczyć ubezpieczającemu tekst ogólnych warunków ubezpieczenia przed zawarciem umowy ubezpieczenia. Tak więc obecnie doręczenie o którym mowa musi nastąpić nie „przy” ale „przed” zawarciem umowy ubezpieczenia. Celem ustawodawcy była tutaj niewątpliwie większa ochrona ubezpieczającego, który powinien dostać tekst ogólnych warunków ubezpieczenia przed zawarciem umowy, tak aby mógł się zapoznać z jego treścią i świadomie podjąć decyzję, czy objąć tą treść stosunkiem umownym. Jednak określenie to pozostaje nadal mało precy- 
zyjne. Aby było ono należycie respektowane, należałoby przyjąć, że ubezpieczający powinien otrzymać tekst ogólnych warunków ubezpieczenia na tyle wcześniej przed zawarciem umowy ubezpieczenia, aby mógł on swobodnie zapoznać się z ich treścią (często dosyć obszerną) i ewentualnie wyjaśnić nasuwające się wątpliwości. Takie jest, jak się wydaje, ratio legis tego unormowania. Jednak, aby mogło to być zrealizowane potrzebne są odpowiednie warunki w miejscach zawierania umów ubezpieczenia i odpowiednie przeszkolenie pracowników, czego realizacja przez zakłady ubezpieczeń wydaje się mało realna. Moim zdaniem w praktyce nic się nie zmieni i nadal pracownik zakładu ubezpieczeń, czy też agent działający w jego imieniu będą doręczać ubezpieczającemu ogólne warunki ubezpieczeń przy wręczaniu zawartej już polisy ubezpieczeniowej chyba, że co bardziej świadomy ubezpieczający poprosi o nie wcześniej.

Ustawodawca wprowadził tez nowe uregulowanie w art. $384 \$ 4$ dotyczące posługiwania się wzorcem umowy w formie elektronicznej. Jeżeli jedna ze stron posługuje się takim wzorcem, to powinna go udostępnić drugiej stronie przed zawarciem umowy w taki sposób, aby mogła ona wzorzec ten przechowywać i odtwarzać w zwykłym toku czynności. Tak więc jeżeli zakład ubezpieczeń będzie chciał posłużć się ogólnymi warunkami ubezpieczenia w postaci elektronicznej (np. przy zawieraniu umowy ubezpieczenia na odległość) będzie musiał, zgodnie z tą regulacją, udostępnić ubezpieczającemu tekst ogólnych warunków ubezpieczenia w takiej postaci jeszcze przed zawarciem umowy ubezpieczenia i to w sposób umożliwiający swobodne przechowywanie i odtwarzanie takiego zapisu elektronicznego.

Istotne znaczenie w systemie regulacji prawnych chroniących interes konsumenta ma reguła interpretacyjna zawarta w art. $385 \$ 2$. Stanowi on, iż wzorzec umowy, a więc także ogólne warunki ubezpieczeń, powinien być sformułowany jednoznacznie i w sposób zrozumiały. Oznacza to, że postanowienia ogólnych warunków ubezpieczeń powinny być sformulowane w taki sposób, aby nie zawierały wyrazów lub zwrotów mających w języku potocznym różne znaczenia. Nie może być tak, że dane postanowienie ogólnych warun- 
ków ubezpieczenia będzie można interpretować na różne sposoby i nie będzie moźliwości określenia, który z tych sposobów jest właściwy. Ogólne warunki ubezpieczeń powinny być także sformułowane w sposób zrozumiały. I tutaj występuje kłopot, ponieważ jest to pojęcie nie do końca precyzyjne. Wynika z niego, że ogólne warunki ubezpieczeń powinny być dla ubezpieczającego zrozumiałe, ale przecież mamy do czynienia z różnego rodzaju ubezpieczającymi - o różnej wiedzy, wykształceniu, poziomie inteligencji itd. Dla jednego ubezpieczającego dane zwroty mogą być zrozumiałe, a dla drugiego nie. Dlatego jedynym, jak się wydaje, rozwiązaniem jest przyjęcie, iż postanowienia zawarte w ogólnych warunkach ubezpieczenia powinny być zrozumiałe dla przeciętnego, „Zwykłego" ubezpieczającego. Określenie takiego uniwersalnego ubezpieczającego wymaga głębszej analizy i powinno nastąpić w doktrynie i orzecznictwie. Ze względu na ramy niniejszego opracowania problematyka ta nie będzie tutaj rozwijana.

Sankcja za niejednoznaczne sformułowania wzorca umowy, określona w zdaniu drugim art. $385 \$ 2$, polega na ich interpretacji zawsze na korzyść konsumenta ${ }^{8}$. W związku z art. $384 \$ 5$ natomiast, sankcją za niejednoznaczne postanowienia ogólnych warunków ubezpieczenia będzie ich interpretacja na korzyść każdego ubezpieczającego, niezależnie od tego czy jest konsumentem, czy też nie. Sytuacja jest tutaj jasna - żaden ubezpieczający nie może ponosić negatywnych skutków wadliwie i niejednoznacznie sformułowanych ogólnych warunków ubezpieczenia, co powinno obciążać zakład ubezpieczeń jako ich twórcę. W nowej ustawie o działalności ubezpieczeniowej ustawodawca posunął się jeszcze dalej i rozszerzył tą korzystną regułę interpretacyjną na inne osoby mogące występować w stosunku ubezpieczeniowym, a nie będące ubezpieczającym. Rozszerzył także obowiązek jednoznaczności i zrozumia-

\footnotetext{
${ }^{8}$ Przyjmuje się, iż zapis ten należy interpretować rozszerzająco i niejednoznaczne postanowienia wzorca umownego tłumaczyć nie tylko na korzyść konsumenta, ale każdej strony z którą profesjonalista zawiera umowę przy użyciu wzorca (również przedsiębiorcy).
} 
lości postanowień również na samą umowę ubezpieczenia. Mianowicie art. 12 ust 3 wspomnianej ustawy stanowi, iż ,ogólne warunki ubezpieczenia oraz umowa ubezpieczenia powinny być formułowane jednoznacznie i w sposób zrozumiały", natomiast ust 4 tego artykułu zawiera rozszerzoną regułę interpretacyjną: „postanowienia sformułowane niejednoznacznie interpretuje się na korzyść ubezpieczającego, ubezpieczonego, uposażonego lub uprawnionego z umowy ubezpieczenia". A więc w razie niejednoznacznego lub niezrozumiałego sformulowania postanowien ogólnych warunków ubezpieczeń oraz, co należy wyraźnie podkreślić, postanowień samej umowy ubezpieczenia, powinno się je interpretować nie tylko na korzyść ubezpieczającego, ale także ubezpieczonego (np. w przypadku, gdy jest to korzystne dla ubezpieczonych przez zakład pracy pracowników), a nawet uposażonego lub uprawnionego z umowy ubezpieczenia. Zmiana ta na pewno przysłuży się lepszej ochronie ubezpieczającego, a zwlaszcza ubezpieczającego konsumenta i co ważne, również konsumenta nie będącego stroną umowy ubezpieczenia, w ich stosunku z zakładem ubezpieczeń. Regulację tą należy uznać za jak najbardziej słuszną i potrzebną.

Wreszcie należy wspomnieć, iż na gruncie ubezpieczeń, w związ$\mathrm{ku} \mathrm{z}$ wprowadzonymi zmianami legislacyjnymi, nowego wymiaru nabiera art. $385^{1}$ k.c. Zgodnie $\mathrm{z}$ nim postanowienia umowy zawieranej $\mathrm{z}$ konsumentem, a obecnie także $\mathrm{z}$ każdym ubezpieczającym, nie uzgodnione indywidualnie nie wiążą go, jeżeli kształtują jego prawa i obowiązki w sposób sprzeczny z dobrymi obyczajami, rażąco naruszając jego interesy. Za nie uzgodnione indywidualnie przepis ten uznaje te postanowienia umowy, na których treść konsument (a w przypadku umowy ubezpieczenia także każdy ubezpieczający) nie mial rzeczywistego wpływu. Sa to tzw. niedozwolone postanowienia umowne lub inaczej klauzule abuzywne. Nie ma wątpliwości, że dotyczą one również ogólnych warunków ubezpieczeń tworzonych przez zakłady ubezpieczeń bez udziału ubezpieczającego. Tak więc jeżeli takie niedozwolone postanowienia umowne znajdą się w ogólnych warunkach ubezpieczenia, to nie będą one wiązać ubezpieczającego, niezależnie od tego czy jest on 
konsumentem, czy też nie. Jest to bardzo istotna ochrona interesów ubezpieczających, którzy nie mają żadnego wpływu na treść ogólnych warunków ubezpieczenia i chcąc zawrzeć umowę ubezpieczenia muszą zgodzić się na włączenie ich treści do łączącego strony umownego stosunku ubezpieczenia. Jednak zgodnie ze zdaniem drugim art. $385^{1}$ nie dotyczy to postanowień określających główne świadczenia stron, w tym cenę lub wynagrodzenie, jeżeli zostały sformułowane w sposób jednoznaczny. Jeżeli więc główne świadczenia stron umowy ubezpieczenia zostały sformułowane jednoznacznie nie będą do nich miały zastosowania regulacje dotyczące niedozwolonych postanowień umownych. Przykładowy katalog niedozwolonych postanowień umownych zawiera art. $385^{3}$ k.c. Część z nich można niewątpliwie odnaleźć w postanowieniach niektórych ogólnych warunków ubezpieczeń i objęcie ochroną wynikającą $\mathrm{z}$ art. $385^{1}$ k.c. konsumentów usług ubezpieczeniowych, a obecnie także każdego ubezpieczającego, należy uznać za rozwiązanie słuszne, wyrównujące pozycje obu stron umowy ubezpieczenia.

\section{Podsumowanie}

Na zakończenie należy stwierdzić, iż stan cywilnoprawnej ochrony konsumenta usługi ubezpieczeniowej cały czas ulega w Polsce wzmocnieniu i jest coraz bliższy, jeżeli już się nie zrównał, z zakresem tej ochrony w państwach Unii Europejskiej. Należy jednak podkreślić, iz jest to proces który trwa $\mathrm{i}$ w miarę rozwoju rynku ubezpieczeń i jego nowych form (np. sprzedaży ubezpieczeń na odległość, za pomocą Internetu, czy też w połączeniu z innymi usługami np. bankowymi) powinien się rozwijać i dostosowywać poziom ochrony konsumenta usług ubezpieczeniowych do pojawiających się potrzeb. Także już istniejące regulacje prawne w tym zakresie wymagają pewnych zmian i korekt. Przede wszystkim należy tu wskazać omawianą w niniejszym opracowaniu regulację art. $384 \$ 5$ k.c., która wprowadza zbyt daleko idącą ochronę ubezpieczającego, odrywając ją od warunku bycia konsumentem. Wprowadziło to nie- 
potrzebne zamieszanie legislacyjne, a przede wszystkim nie mieści się w argumentacji uzasadniającej celowość wprowadzania specjalnej ochrony prawnej określonej grupy podmiotów jakimi są konsumenci. Regulację tą należałoby uchylić lub zmienić - pewne propozycje w tym względzie przedstawiono również w niniejszym opracowaniu. Generalnie proces rozwoju regulacji prawnych zapewniających ochronę ubezpieczającego konsumenta podąża, jak się wydaje, w dobrym kierunku, lecz caly czas wymaga pogłębionej analizy ze strony doktryny w celu wypracowania jak najlepszego jego modelu oraz odpowiedniej interpretacji w orzecznictwie sądowym.

\section{Protection of Personal Data of Consumers \\ of Insurance SERVICES IN POLAND}

\section{Summary}

The article analyses the regulations of Polish civil law, which were introduced to protect a consumer of insurance services who, as a weaker party of a insurance agreement needs such protection. It presents main changes of the insurance law in this respect, introduced on May 01, 2004 as a part of the process of adapting Polish legal system to the EU legislation. Amongst other things, the author discusses the following issues: legal definition of a "consumer”, scope of legal measures on protection of the insured, legal character of the general terms and conditions of the insurance agreements issued by insurance companies and forbidden contractual clauses. The author also suggests changes to these laws in order to improve them and make them more precise. 